\title{
URBANISTIKOS PAVELDO TVARKYBOS IŠTAKOS IR ŠIANDIENINĖ SITUACIJA LIETUVOJE
}

\author{
Dalia Dijokienè \\ Urbanistikos katedra, Vilniaus Gedimino technikos universitetas, \\ Pylimo g. 26/Trakug. 1, 01132 Vilnius, Lietuva \\ El.paštasdijokai@takas.lt \\ Iteikta $2011-10-18$
}

\begin{abstract}
Santrauka. Urbanistikos paveldo vertybės sąvoka žmonijos sąmonèje yra palyginti nauja. Pasaulio materialiojo nekilnojamojo kultūros paveldo apsaugos raidoje urbanistikos paveldo objektai pradèti saugoti vèliausiai. Jų apsauga formavosi kaip priešprieša dominuojantiems urbanizacijos procesams. Straipsnyje glaustai apžvelgiama, kaip kito kultūros paveldo sąvoka ir objektas XX-XXI a. tarptautinių organizacijų dokumentuose ir kada šią sąvoką papildo urbanistiniai dariniai. Analizuojamas Lietuvos urbanistikos paveldotyros mokslinis pagrindas, lèmęs urbanistikos vertybių nustatymą ir ịteisinimą. Aptariamas dabartinis teisinis urbanistikos paveldo tvarkybos pagrindas ir jo trūkumai. Ieškoma nesusikalbejjimo tarp mokslo ir teisès atstovų, valdininkijos ir piliečių urbanistikos paveldo tvarkybos klausimais priežasčių.
\end{abstract}

Reikšminiai žodžiai: miestas, senamiestis, istorinis centras, urbanistikos paveldas, urbanistikos paveldo vertybe், istoriškai susiformavusių urbanistinių struktūrų vystymasis, nekilnojamasis kultūros paveldas, reglamentavimas.

\section{Ivadas}

Beveik visų didžiųjų Lietuvos miestų centrinès dalys turi istoriškai susiklosčiusias vertingas urbanistines struktūras - senamiesčius, istorinius miestų branduolius ar miesto užuomazgą menančius urbanistinius darinius. Dažną kartą centrinès miesto dalies urbanistinè renovacija priklauso ir nuo istorinių miesto dalių tvarkymo koncepcijų. Lietuvoje esame paveldejję išsamią mokslinę tiriamąją urbanistikos paveldo vertybių nustatymo metodiką, apsaugai igyvendinti yra sukurta teisinè bazè, tvarkymui realizuoti paruošti ir ruošiami reglamentai, tačiau istorinių miesto dalių vystymo(si) procesas yra beveik nevaldomas: arba vyksta chaotiškai, arba nevyksta visai. Straipsnyje ieškoma atsakymų i klausimą - kas lemia urbanistikos paveldo tvarkybos neveiklumą Lietuvoje? Siekdama šio tikslo autore glaustai apžvelgia, kaip kito kultūros paveldo sąvoka ir objektas XX-XXI a. tarptautinių organizacijų dokumentuose, skirtuose kultūros paveldo apsaugai (daug platesnè studija atlikta neseniai išleistoje autorès monografijoje - Dijokienè 2009). Akcentuojama, kada pa- veldo objekto sąvoką papildo urbanistiniai dariniai. Taip pat autorè apžvelgia Lietuvos urbanistikos paveldotyros mokslinį ir tvarkybos teisinị pagrindą, ieško nesusikalbėjimo tarp mokslininkų, teisès sergètojų valdininkų bei Lietuvos gyventojų - turto paveldètojų priežasčių ir bando izžvelgti ateities perspektyvas.

Straipsnyje autorès vartojamas terminas urbanistikos paveldo tvarkyba apima visas sritis - vertybių nustatymą, itteisinimą, apsaugą ir tvarkymą (angliškas termino atitikmuo - management). Lietuvos Respublikos nekilnojamojo kultūros paveldo apsaugos įstatyme šis terminas vartojamas siauresne sąvoka: „tvarkyba kultūros paveldui išsaugoti atliekami darbai: tyrimas (taikomasis), remontas, avarijos grèsmès pašalinimas, konservavimas, pritaikymas, restauravimas, atkūrimas, šių darbų planavimas ir projektavimas“" (Lietuvos... 2004). Autorès nuomone, didelio prieštaravimo tarp šio termino traktavimo nèra, nes tiek vienu, tiek kitu atveju sąvoka apima ne tik konkrečius tvarkymo darbus, bet ir tiriamąją bei projektinę veiklą. 


\section{Urbanistikos paveldas tarptautiniuose dokumentuose}

Urbanistinio paveldo vertybès - tai sąvoka, kuri žmonijos sąmoneje yra palyginti nauja. Kiekvienas reiškinys turi savo pradžią, raidą ir kaitą. Kultūros paveldo objekto sąvoka ir jos turinys kito. Iki pat XIX a. pradžios nei europiečiai, nei amerikiečiai nesiejo savo tapatumo su materialiuoju paveldu. Fizinès praeities liekanos tapo svarbios tik tuomet, kai buvo suvokta, kad kiekvienos tautos ar epochos istorija yra unikali ir nepakartojama (Čepaitienè 2005: 77). Nors Specializuotas erudicinis interesas kultūros vertybių apsaugai ir tyrimui išryškejjo Renesanso epochoje ir klestejjo XVII-XVIII a. (Čepaitienè 2005: 38), didelis pasaulio tautų susidomejjimas savo praeitimi, jos paminklu išsaugojimu gimsta tik XIX a. ir pasireiškia įvairių istorinès pakraipos mokslo draugijų bei apsaugos visuomeninių organizacijų steigimu ir veikla. Tačiau reikia pastebèti, kad pasaulio materialiojo nekilnojamojo kultūros paveldo apsaugos raidoje urbanistikos paveldo objektai pradèti saugoti vèliausiai (Miškinis 2005: 5).

Platų kultūros paveldo apsaugos judejimą tarptautiniu mastu pradèjo pirmasis tarptautinis istorijos paminklų architektų ir technikų kongresas, susirinkęs Atènuose $1931 \mathrm{~m}$. ir priemęs Atènų chartiją, kuri nubrèže pagrindinius kultūros paveldo apsaugos principus. Atskirose šalyse buvo rengiami nacionaliniai dokumentai, buvo plètojama UNESCO (United Nations Educational, Scientific and Cultural Organization Jungtinių Tautų švietimo, mokslo ir kultūros organizacija, įkurta 1945 m.) ir ICOMOS (International Council of Monuments and Sites - Tarptautinè paminklų ir vietovių apsaugos taryba, įkurta $1965 \mathrm{~m}$., kultūros paveldo srityje yra UNESCO ekspertas) veikla, ikurtas kultūros vertybių tyrimo ir konservavimo Tarptautinis centras (Tarptautinè... 1964). Atènu chartijoje kultūros paveldo objektas yra istorinis paminklas (The Athens Charter... 1931). Ši sąvoka apima daugiau pavienius objektus (ne tik pastatus). $1954 \mathrm{~m}$. Hagoje priimta Kultūros vertybiu apsaugos ginkluoto konflikto atveju konvencija konkretina, kas yra laikoma kultūros vertybe - tai „kilnojamosios ir nekilnoja mosios vertybès: architektūros, dailès ir istorijos paminklai; archeologinès vietovés; pastatų grupés, kurių visuma turi istorinę ar meninę vertę; meno kūriniai; rankraščiai, knygos" (Kultūros... 1954). Pirmieji XX a. tarptautiniai dokumentai buvo skirti ryškiausių kultūros paveldo objektų apsaugai reglamentuoti, šie objektai ne viename dokumente ìvardinami kaip paminklai.

Septintajame ir aštuntajame XX a. dešimtmečiuose priimamuose tarptautiniuose dokumentuose imama plèsti kultūros paveldo objekto sąvoka - ji jau apima „ir atskirą kūrini, ir miesto ar kaimo tipo kompleksus, kurie yra tam tikros civilizacijos evoliucijos ar atskiro istorinio ịvykio liudininkai“" (Tarptautinè... 1964). Architektūriniu-urbanistiniu paveldu ịvardinami tiek pastatai, tiek jų grupès ir vietovès (Resolution... 1968; First Conference... 1969). Dar vienas labai įdomus ir savo idejomis novatoriškas dokumentas yra $1967 \mathrm{~m}$. ICOMOS priimtos Quito normos. Šiame dokumente iškeliama erdvès, kaip neatskiriamos paminklinių objektų dalies, idejja. Raginama atkreipti dèmesị $\mathfrak{i}$ urbanistinị paminklo kontekstą ar gamtinę aplinką. Taip pat teigiama, kad paminkline zona, struktūra ar vietove galima vadinti ir tokią, kuri yra vertinga kaip kompleksas, nors atskiri jos elementai išskirtinès vertès neturi (The Norms... 1967). Urbanistiniu objekty paveldas vis dar telpa architektūros paveldo sąvokoje, nors paveldo objekto sampratoje atsiranda ir naujų atspalvių - propaguojama saugoti ne tik atskirus statinius, bet ir miestų bei kaimų rajonus, ištisus urbanistinius kompleksus. 1975 m. atkreipiamas dèmesys ị mažesnius istorinius miestus - urbanistinio paveldo dali (Resolutions... 1975).

Urbanistinio kultūros paveldo samprata bei sąvoka miestu paveldas Europoje ir visame pasaulyje, galima sakyti, ịsitvirtina devintajame XX a. dešimtmetyje. Miestu paveldas - tai asmens ir vietos vienové, todèl jų apsauga - ne pavienių statinių, bet visos vietovès, jos istorinio savitumo apsauga. $1987 \mathrm{~m}$. spalio $15 \mathrm{~d}$. Vašingtone ICOMOS prièmè Istoriniu miestu apsaugos chartija (Vašingtono chartija). Joje rašoma: „Ši chartija skirta didelèms ir mažoms urbanistinèms vietovèms bei miestams, istoriniams jų centrams arba kvartalams su visa natūralia ir žmogaus sukurta aplinka“. Chartija apibrèžia miesto vertybes, kurios turètų būti saugomos kaip urbanizuotos zonos istorine išraiška, jo materialiųjų ir estetinių elementų sankaupa:

- išorinis miesto vaizdas, kuris priklauso nuo planinès ir erdvinès jo struktūros;

- įvairių miesto erdvių - apstatytų kvartalų, laisvų ir naudojamų želdinių plotų - santykis;

- pastatų forma ir vidiné bei išorinè išraiška, kuri priklauso nuo tų pastatų struktūros, tūrių, stiliaus, mastelio, medžiagų, spalvų bei dekoro elementų;

- miesto ir urbanistinių zonų santykis su aplinka natūralia arba žmogaus sukurta;

- ìvairūs miesto ar urbanistinès zonos savitumai, kuriais jis pasipilde istorinèje raidoje (Istorinių... 1987).

Urbanistiniu paveldu imami vadinti ne tik istoriniai miestų centrai ar mažesni miestai, bet ir mažos gyvenvietès (Declaration... 1982). Urbanistinio kultūrinio paveldo samprata dar papildoma urbanistinès atviros erdvès sąvoka, nes pripažįstama, kad atvirų 
erdvių formos yra neatsiejama urbanistinès aplinkos ir istorinio miesto paveldo dalis (Recommendation... 1986). Taigi devintajam dešimtmečiui buvo būdinga labai plati urbanistinio kultūros paveldo objekto sąvokos interpretacija.

$2003 \mathrm{~m}$. ICOMOS priimtuose dokumentuose urbanistinio paveldo sąvokos turini papildo tokie dèmenys, kaip istorinis rajonas (historic district), apimantis istorinio kaimo ir miesto kvartalo sąvokas, kultūrinis kontekstas, be kurio negali būti suvokiamas ir vertinamas joks materialusis paveldas (ICOMOS charter... 2003). 2005 m. UNESCO priimtame Vienos memorandume atrandama istorinio urbanistinio kraštovaizdžio sąvoka, aprèpianti jau tradiciniais tapusius tokius terminus, kaip istorinis centras, ansamblis, apsuptis (Vienna... 2005). Tais pačiais metais pasirodžiusioje $X{ }^{\prime}$ an deklaracijoje (ICOMOS) tarptautinès bendruomenès demesys atkreipiamas it paveldo statinių, vietovių ir zonų aplinkos apsaugą. Deklaracijoje teigiama, kad aplinkos pokyčiai turètų būti valdomi taip, kad ji neprarastų savito charakterio ir kultūrinio reikšmin- gumo (Xi'an... 2005). O naujausias ICOMOS dokumentas yra skirtas vietos dvasiai (spirit of place) išsaugoti. 2008 m. priimtoje Kvebeko deklaracijoje teigiama, kad vietos dvasią charakterizuoja materialūs (pastatai, vietos, kraštovaizdžiai, keliai, objektai) ir nematerialūs elementai (atsiminimai, pasakojimai, ritualai, festivaliai, tradicijos), fiziniai ir dvasiniai elementai, kurie suteikia vietai prasmę, vertę, emocijų ir mịslingumo. Vietos dvasia perteikia visapusiškesnị supratimą apie gyvensenos būdą ir nusako laiko tèkmèje susiformavusi paminklų, vietovių ir kultūrinio kraštovaizdžio charakteri (Quebec Declaration... 2008).

Glausta kultūros paveldo objekto sampratos kaitos apžvalga tarptautinių pasaulio (UNESCO, ICOMOS) ir Europos regiono (Europos Taryba) organizacijų dokumentuose atskleidé, kada ir kaip nuo pavienių objektų ateita iki urbanistinių darinių apsaugos (1 pav.)*. Būtų galima teigti, kad pradejus vertinti miesto istorinès raidos ir kaitos ženklus, istorinio urbanistinio paveldo apsauga formavosi kaip priešprieša dominuojantiems urbanizacijos procesams (Čepaitienè 2010: 140).

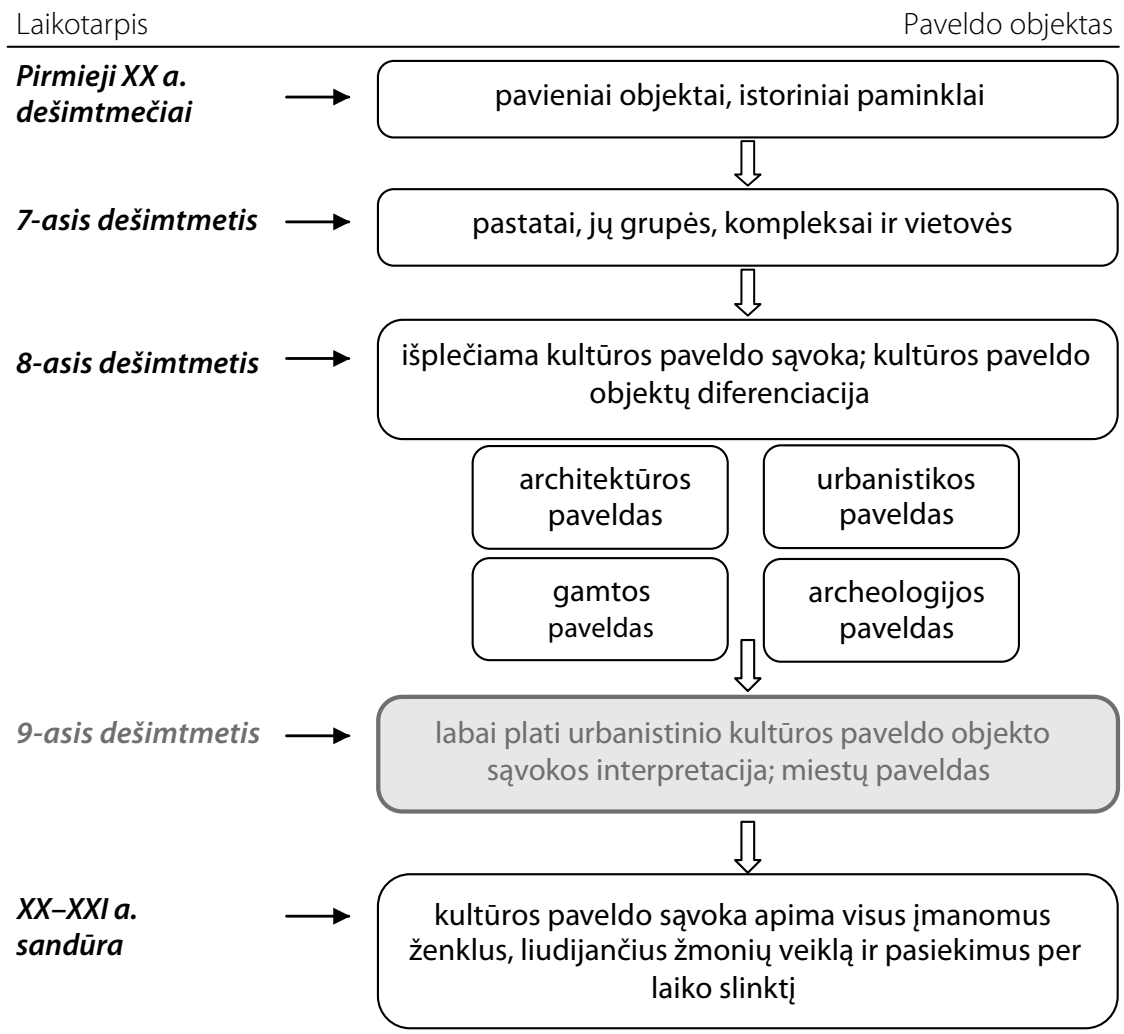

1 pav. Kultūros paveldo objekto sampratos kaita XX-XXI a. (Dijokienè 2002, 2009)

Fig. 1. Evolution of the concept of a cultural heritage object in the 20th and 21st centuries (Dijokienè 2002, 2009)

Straipsnyje apžvelgiami ne tik pasaulinių organizacijų dokumentai (UNESCO, ICOMOS), bet ir atkreipiamas dèmesys $\mathfrak{i}$ Europos regiono (Europos Tarybos) dokumentus. Straipsnio autores nuomone, Lietuvai esant šio regiono dalimi, tai yra tikslinga. 


\section{Moksliniai urbanistikos paveldo tyrimai, vertybès ir jų nustatymo metodika Lietuvoje}

Urbanistikos vertybiu pripažinimo raida. Nors $1936 \mathrm{~m}$. Vilniaus senamiestis buvo itteisintas kaip Lenkijos reliktas, $1949 \mathrm{~m}$. buvo paskelbtas vienu iš 20-ties svarbiausių TSRS miestų ir tais pačiais metais Vilniaus, Kauno, Klaipedos ir Kèdainių senamiesčiai buvo įtraukti ị Lietuvos architektūros paminklų sąrašą, realiai moksliniai urbanistikos paveldo tyrimai Lietuvoje prasidejo šeštajame XX a. dešimtmetyje. Šioje srityje dirbo ne vienas iškilus Lietuvos urbanistas ir architektas (K. Šešelgis, A. Miškinis, A. Pilypaitis, V. Jurkštas, A. Spelskis, J. Baršauskas ir kiti).

Pradiniame Lietuvos urbanistikos paveldo vertingų objektų nustatymo ir ịteisinimo etape darbą atliko architektai Algimantas Miškinis ir Antanas Pilypaitis. Pirmasis tyrinèjo visą Lietuvos urbanistikos paveldą (darbą pradèjo $1955 \mathrm{~m}$.), o antrasis - planingai formuotus XVI a. antroje pusèje - XVIII a. Lietuvos miestus ir miestelius (darbą pradejo 1958 m.). Pagal šių tyrimų rezultatus $1967 \mathrm{~m}$. buvo sudarytas bendras vertingu urbanistikos paveldo objektų sąrašas, pateiktas specialistams svarstyti ir iteisinti, $1969 \mathrm{~m}$. sausio $27 \mathrm{~d}$. jis buvo aprobuotas (Miškinis 2005: 6). Sudarant saugotinų objektų sąrašą stengtasi atrinkti ir apsaugoti būdingiausius ir vertingiausius Lietuvos miestų bei miestelių visų trijų planinių tipų (linijinio, spindulinio, stačiakampio) charakteringus ir retus, bet savitus atstovus. Atstovai parinkti pagal:

- skirtingą planų struktūrą bei jų susiklostymo pobūdị (savaiminis, planuotas), laiką ir regioną;

- centrų-aikščių formas ir tipus;

- būdingą atskiriems tipams išsidèstymą gamtovaizdyje;
- senojo plano ir užstatymo išlikimo laipsni (grynumą, dabar sakytume „autentiškumą“) (Miškinis 2005: 12).

Nuo $1967 \mathrm{~m}$. vertingų urbanistikos objektų sąrašas buvo tikslinamas ir padarius paskutinius pakeitimus (1989 m.) vietinès reikšmès urbanistikos paminklų sąraše liko 60 pozicijų, o respublikinès reikšmès senamiesčiu - 7 (Vilnius, Kaunas, Klaipeda, Trakai, Kèdainiai, Telšiai ir Ukmergè) (Miškinis 2005: 22), (žr. 2 pav.).

1970-1978 m. buvo vykdomi detalūs vietinès reikšmés urbanistikos objektų (61 objekto, Telšiai ir Ukmergé pateko į šių objektų sąrašą, nes respublikinès reikšmès jie buvo pripažinti tik $1989 \mathrm{~m}$.) istorinès urbanistinès raidos tyrimai, leidę nustatyti, kokius plano ir tūrinès erdvinès kompozicijos elementus ir formas reikia saugoti bei kokioje teritorijoje tie vertingi elementai ir formos yra, parengtos vertingų teritorijų ir jų apsaugos zonų ribos (žr. 3 pav.). Lygiagrečiai su šiais darbais buvo rengiami respublikinès reikšmès senamiesčių regeneracijos projektai: Vilniaus (I - 19561959 m., II - 1972-1974 m., III - 1988-1992 m.), Kauno (I - 1959-1961 m., II - 1975-1977 m.), Klaipèdos (I 1961-1963 m., II - 1973-1975 m.), Kèdainių (1964 m.). Rengiant šiuos projektus, atlikti ịvairūs tūrinès erdvinès senamiesčių sanklodos tyrimai, apibendrintos ir nusaky tos tiek vertybių nustatymo, tiek jų tyrimo, tiek perspektyvinio modeliavimo metodikos (Шешельгис 1963; Jurkštas 1975). Nuoseklią ir detalizuotą urbanistinio objekto tyrimo metodiką iliustruoja darbo $v y k d y$ mo schema, pateikta kaip 1986 m. parengtos Metodines rekomendacijos senosios ir naujosios architektūros integravimui projektuojant LTSR istorinius miestus priedas (Miškinis 2005: 147-170). Metodika apima tiek plačius

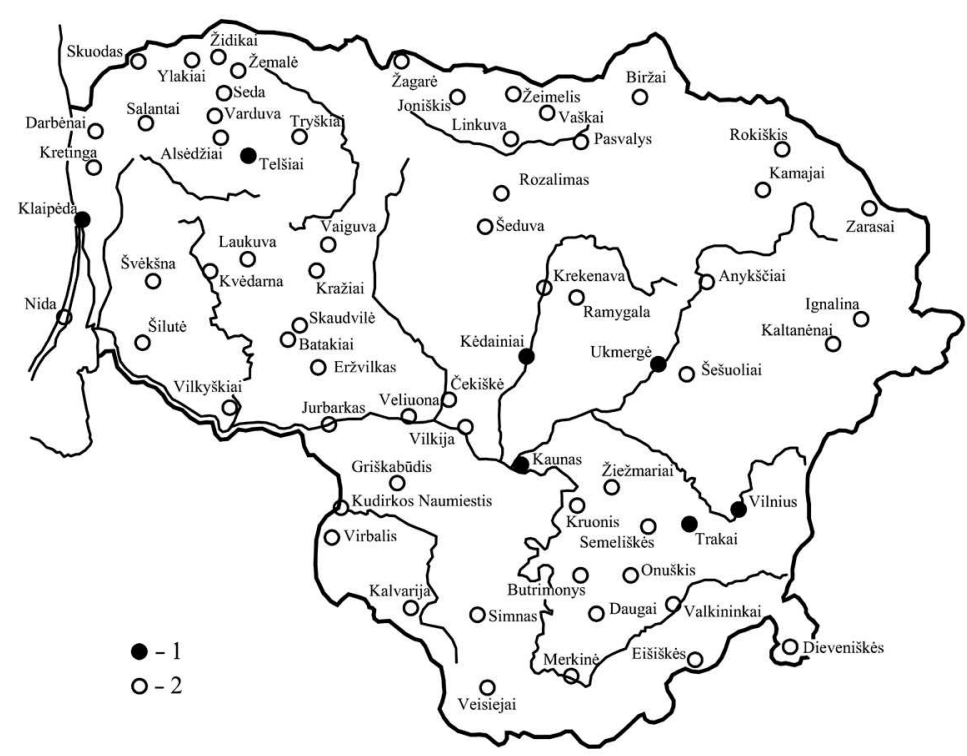

2 pav. Vertingu urbanistikos objektu sklaida, 1989 m. situacija (1 - respublikinès reikšmès, 2 - vietinès reikšmès)

Fig. 2. Spread of valuable urban objects, situation of 1989 (1 - national importance, 2 - local importance) 
A
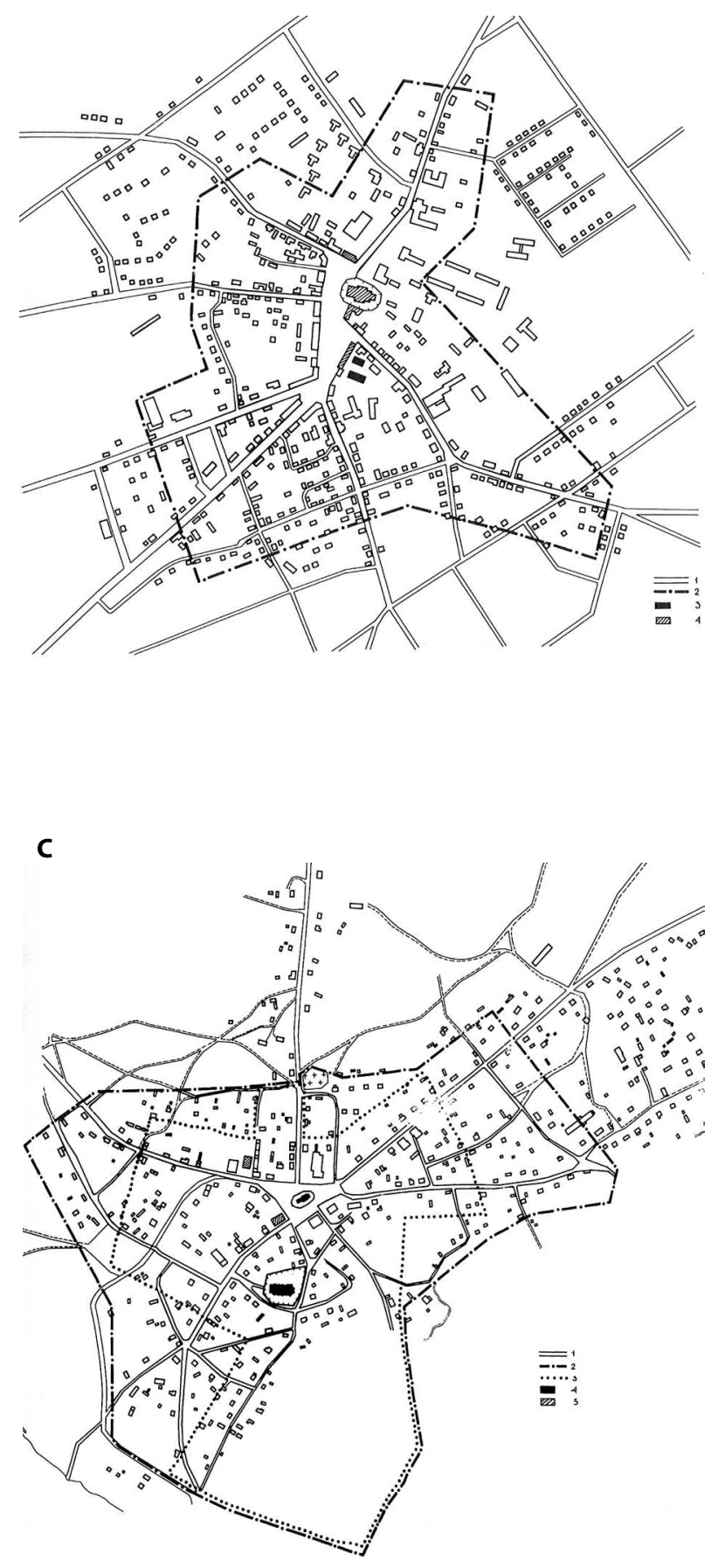

B

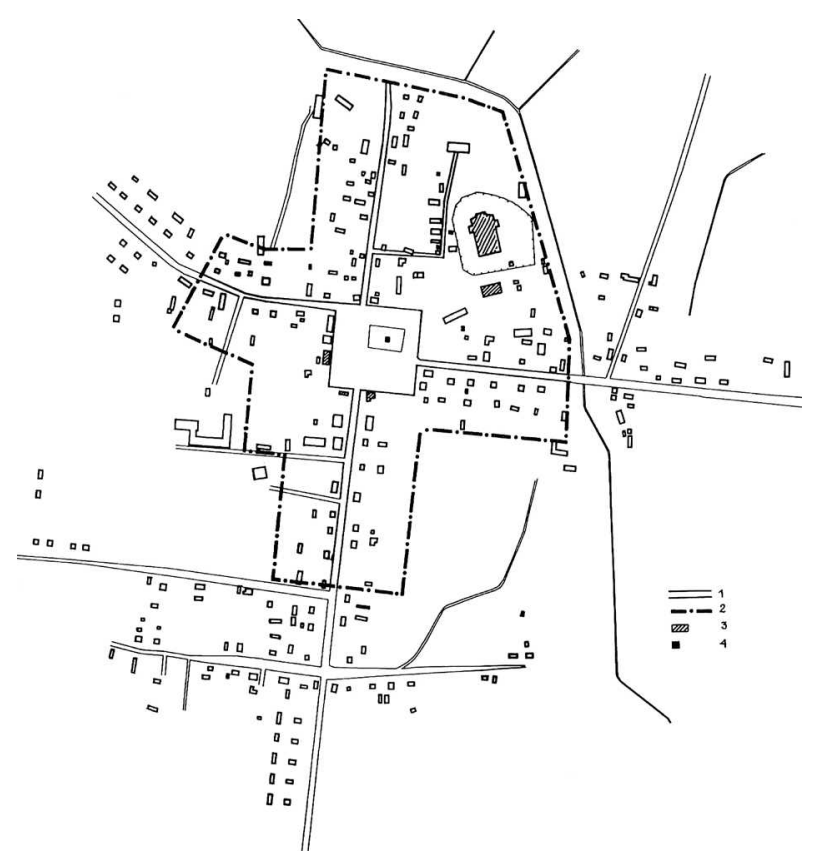

D

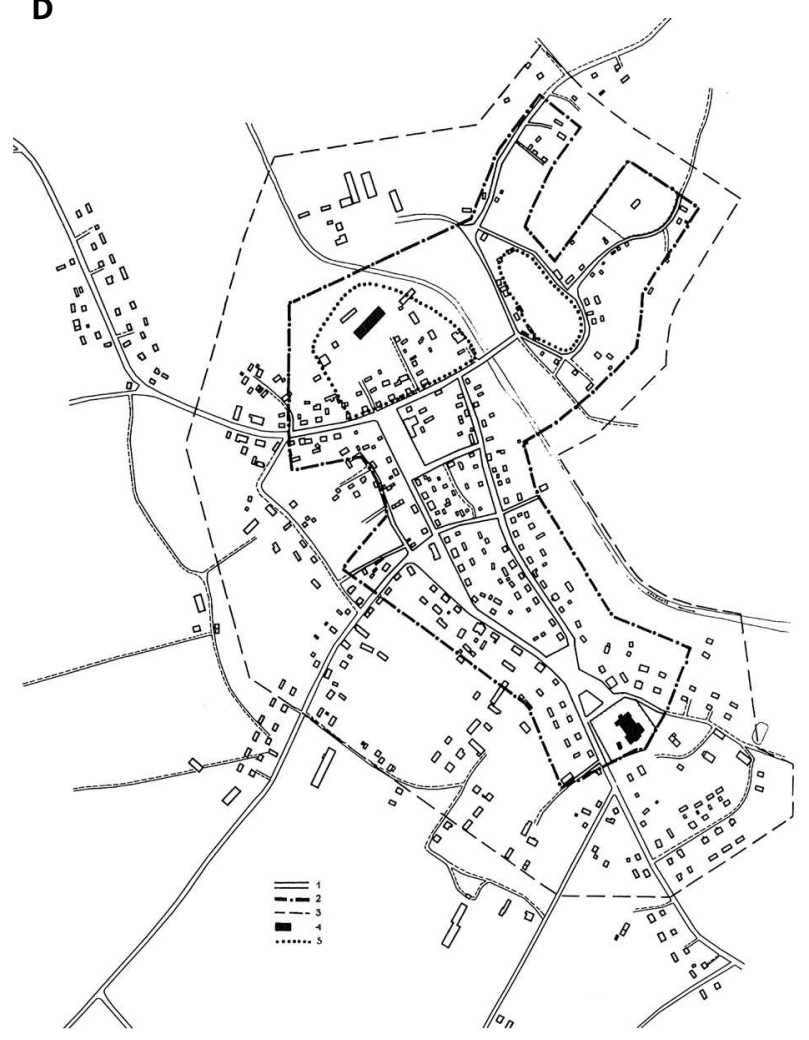


E

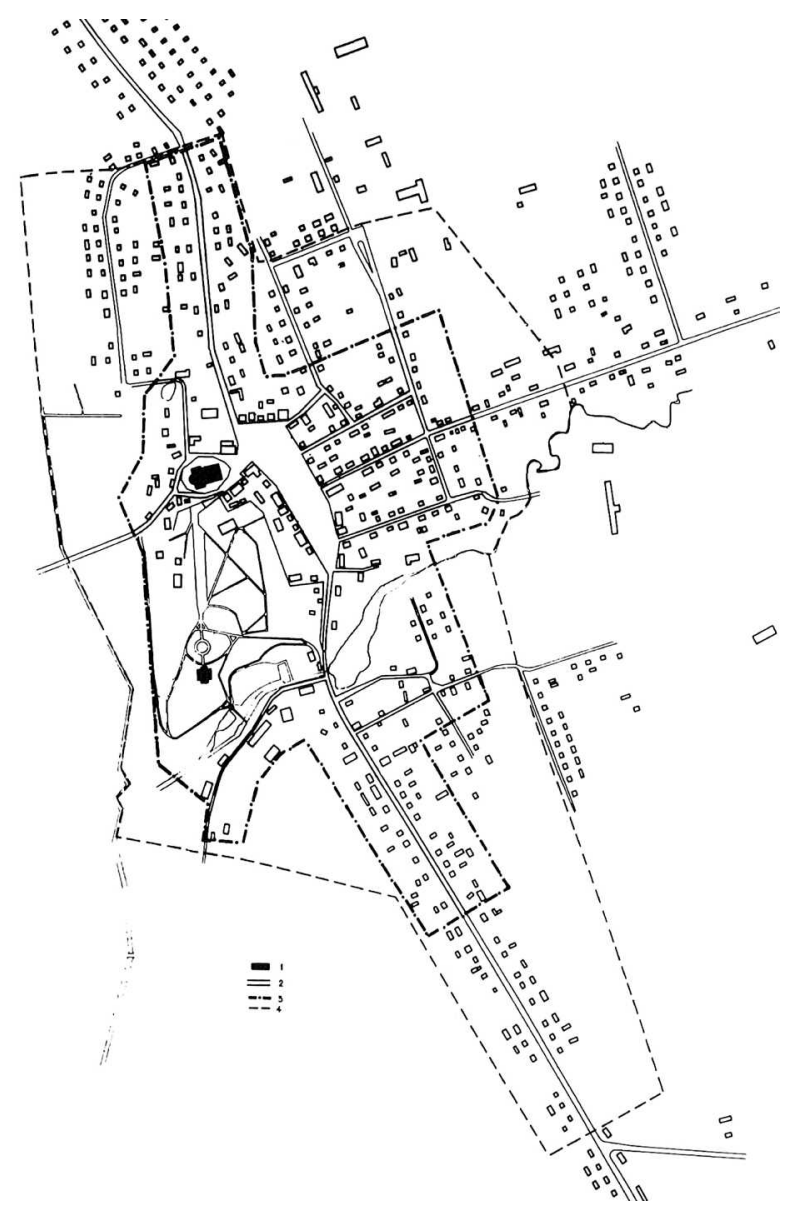

G

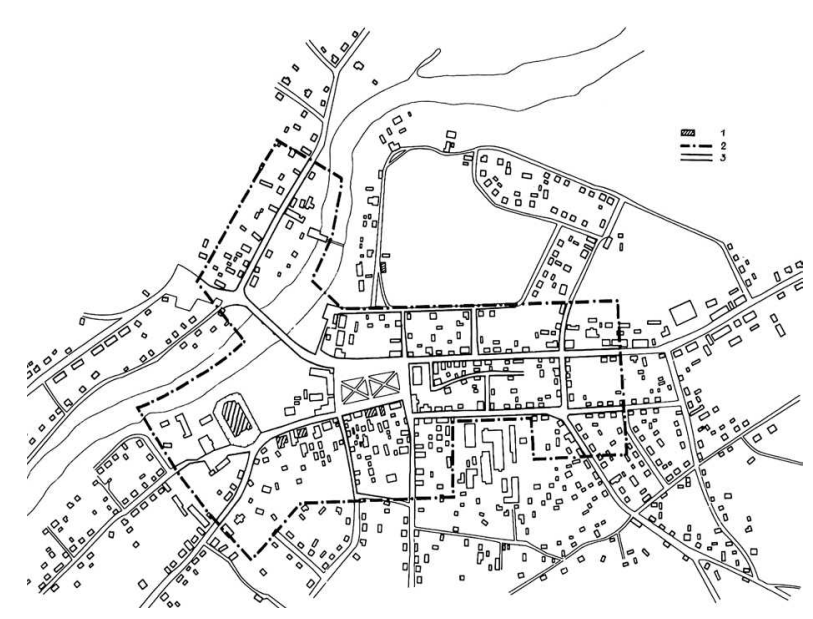

$\mathbf{F}$

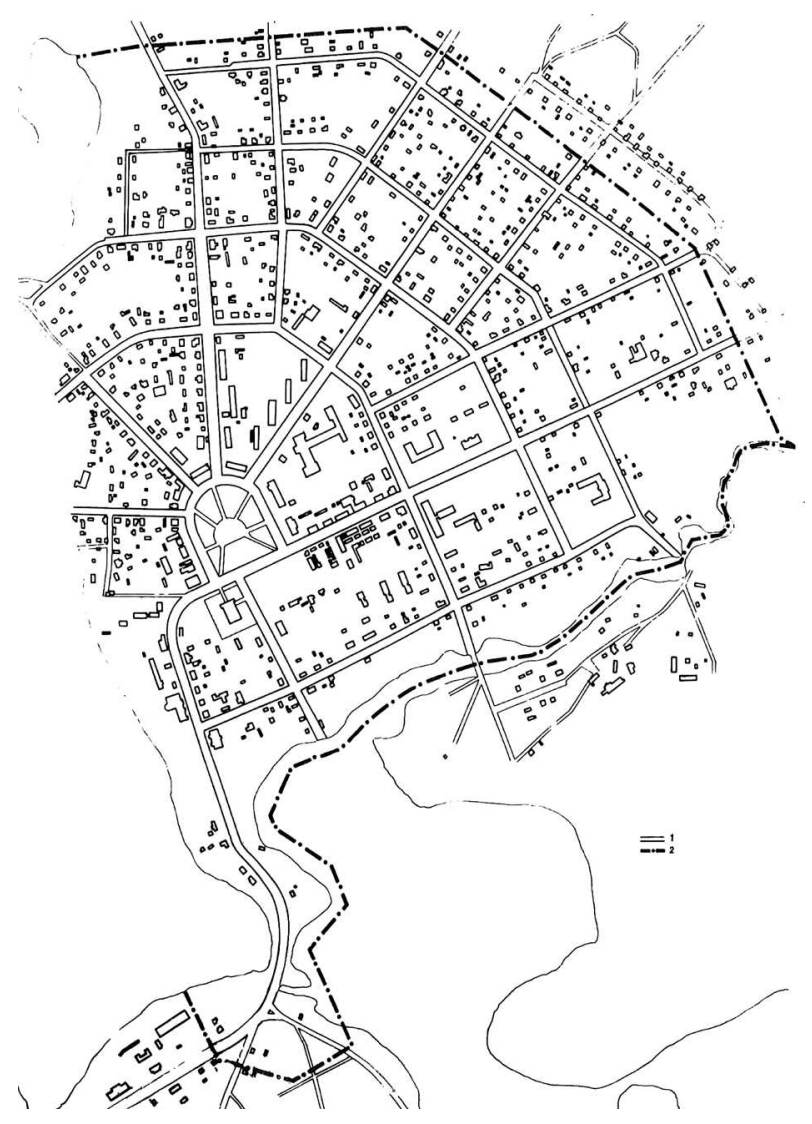

H

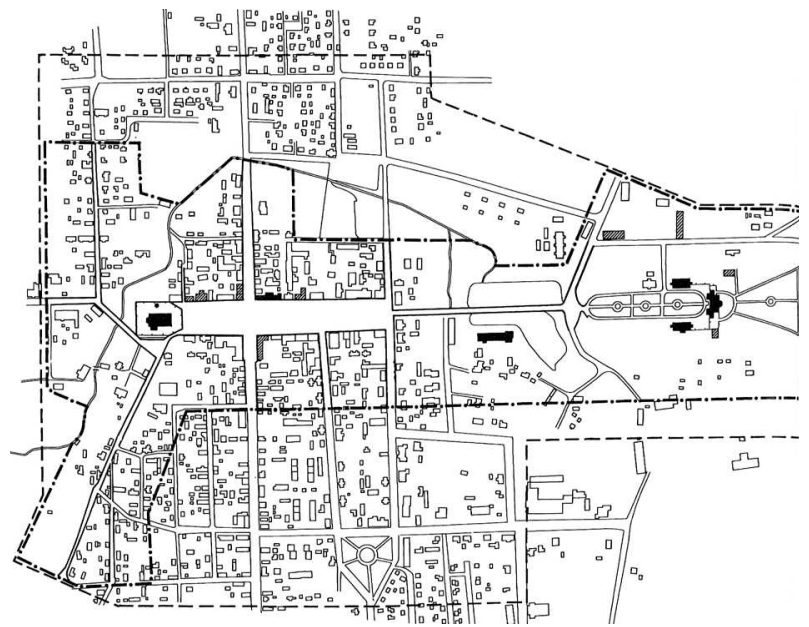

3 pav. Miestụ ir miestelių vertingụ teritorijų ribų schemų pavyzdžiai (A - Joniškis, B - Kamajai, C - Merkinė, D - Kražiai, E - Švejkšna, F - Zarasai, G - Anykščiai, H - Rokiškis, pagal Miškinis, 2005)

Fig. 3. Example schemes of the borders of valuable territories in towns and small towns ( $A$ - Joniškis, $B$ - Kamajai, $C$ - Merkine, D - Kražiai, E - Švėkšna, F - Zarasai, G - Anykščiai, H - Rokiškis according to A. Miškinis, 2005). 
esamos būklès tyrimus, tiek architektūrinio urbanistinio teritorijos formavimo koncepciją, pagrịstą vertybių apsauga ir galima pletra.

Septintajame-aštuntajame XX a. dešimtmečiuose Lietuvoje buvo sukurta neabejotinai vienintele tarp Sovietų Sąungos respublikų mokslinių ir praktinių priemonių sistema vienos rūšies materialiajam paveldui saugoti ir tvarkyti. Iki $1991 \mathrm{~m}$. ši sistema veikè nepriekaištingai tiek, kiek tai galèjo būti ịmanoma totalitarineje valstybeje (Miškinis 2005: 6).

XX-XXI a. sandūroje vèl grịžtama prie urbanistikos paveldo vertybių inventorizavimo. 1990-1995 m. atliekami tyrimai didžiuosiuose Lietuvos miestuose (Vilniuje, Kaune ir Klaipedoje), tyrimų tikslas - nustatyti saugotinas urbanistikos paveldo teritorijas, esančias $1940 \mathrm{~m}$. administracinèse miestų ribose (Jurevičienè et al. 1990; Pilypaitis et al. 1993; Bučas 1995). Nuo 1995 m. atnaujinami 1969 m. vietos reikšmès urbanistikos paminklais paskelbtų objektų tyrimai, siekiant išsiaiškinti nuo to laiko ịvykusius pasikeitimus juose. Taip pat tiriami visi miestai ir miesteliai, atsiradę iki 1940 m., ivvardijama, kuo išsiskiriantis, savitas ir unikalus Lietuvos urbanistikos paveldas. Tyrimuc medžiaga publikuojama monografijose (Miškinis 1999, 2002, 2004, 2005, 2007, 2009). XXI a. urbanistikos paveldo objektų kokybiniai tyrimai atliekami pasitelkiant ne tik vizualinius natūros stebejjimus bei grafinę stebimų objektų analizę, bet ir naudojant šiuolaikines kompiuterines programines ịrangas (Zaleckis, Matijošaitienè 2011).
Šią glaustą urbanistikos paveldo mokslinių tyrimų ir vertybių nustatymo retrospektyvą Lietuvoje galima būtų išreikšti tokia tendencija:

- darbų pradžioje vyravo kiekybiniai tyrimai, jų tikslas buvo atrinkti tuos atstovus, kurie atspindètu urbanistikos paveldo savitumus Lietuvoje;

- vèliau vyko kokybiniai tyrimai (kai kurie lygiagrečiai ir su kiekybiniais) - atliekami detalūs urbanistinių objektų tyrimai, nusakomos vertybès, apibrèžiamos jų teritorijos, modeliuojama perspektyvine plètra;

- atgavus Lietuvos nepriklausomybę, po $1990 \mathrm{~m}$. vèl grịžtama prie kiekybiniu urbanistikos paveldo objektų tyrimų - naujos teritorijos igauna paveldosauginị statusą. Kokybinių tyrimų mažèja (žr. lentelę).

Ši tendencija kelia pavojų - neįsisąmoninus urbanistinio paveldo vertybių išskyrimo tikslo respektuoti miesto istorine raida ir jo savituma, saugojimo diapazonas gali netekti ribų, o pats saugojimas tapti nepakeliama našta tiek gyventojams, tiek valstybei.

Praejjęs šimtmetis pasižymèjo brandžiais Lietuvos urbanistikos paveldo moksliniais tyrimais, kurie savo laikotarpiu netgi pranoko tarptautinę minti - miestu pavelda respektuojanti chartija priimta $1987 \mathrm{~m}$., o Lietuvoje jau nuo $1969 \mathrm{~m}$. tvirtinami urbanistikos vertybių sąrašai ir vykdomi tiriamieji darbai.

Urbanistikos paveldo vertybès squvoka. Apibendrinant urbanistikos paveldo mokslinių tyrimų skyrių, reiktų nusakyti, kas yra urbanistikos paveldo vertybè.

Lentelè. XX a. urbanistikos mokslinès paveldotyros Lietuvoje retrospektyva

Table. Retrospect of urban heritage scientific research in Lithuanian in the $20^{\text {th }}$ century

\begin{tabular}{|c|c|c|c|c|c|}
\hline \multirow[t]{2}{*}{ Vykdyta veikla } & \multicolumn{5}{|l|}{ Laikotarpis } \\
\hline & $\begin{array}{l}\text { XX a. 6-7-asis } \\
\text { dešimtmečiai }\end{array}$ & $\begin{array}{l}\text { 8-asis } \\
\text { dešimtmetis }\end{array}$ & $\begin{array}{l}\text { 9-asis } \\
\text { dešimtmetis }\end{array}$ & $\begin{array}{l}\text { 10-asis } \\
\text { dešimtmetis }\end{array}$ & $\begin{array}{l}\mathrm{XX}-\mathrm{XXI} \text { a. } \\
\text { sandūra }\end{array}$ \\
\hline $\begin{array}{l}\text { - urbanistikos paveldo objektu sąrašu } \\
\text { sudarymas }\end{array}$ & 1955-1969 & & & & \\
\hline $\begin{array}{l}\text { - urbanistikos paveldo objektų vertybių } \\
\text { apibrěžimas ir teritorijų ribų nustatymas }\end{array}$ & & 1970-1978 & & & \\
\hline $\begin{array}{l}\text { - urbanistikos paveldo vertybiu } \\
\text { nustatymo, tyrimo, perspektyvinio } \\
\text { modeliavimo metodiku parengimas }\end{array}$ & & & 1979-1986 & & \\
\hline - regeneracijos projektų rengimas & 1956-1992 & & & & \\
\hline $\begin{array}{l}\text { - didžiujų Lietuvos miestu } \\
\text { saugotinu teritoriju } 1940 \text { m. miestu } \\
\text { administracinèse ribose nustatymas }\end{array}$ & & & & 1990-1995 & \\
\hline $\begin{array}{l}\text { - viso urbanistikos paveldo, atsiradusio iki } \\
1940 \text { m., inventorizavimas }\end{array}$ & & & & & $1995-\ldots$ \\
\hline Vykdytos veiklos apibūdinimas & $\begin{array}{l}\text { dominuoja } \\
\text { kiekybiniai tyrimai }\end{array}$ & $\begin{array}{l}\text { dominuoja } \\
\text { kokybiniai ty }\end{array}$ & /rimai & $\begin{array}{l}\text { dominuoja } \\
\text { kiekybiniai }\end{array}$ & $\begin{array}{l}\text { yrimai } \\
\rightarrow \quad ?\end{array}$ \\
\hline
\end{tabular}


Čia vertètų pacituoti mokslininką A. Miškinit, daugiausiai nuveikusị šioje srityje: „Urbanistikos paveldo vertybėmis laikomos tos plano, užstatymo, tūrinès ir erdvinès kompozicijos visumos dalys, elementai ir formos, kurios: 1) yra reikšmingos viso Lietuvos urbanistikos paveldo ar atskirų jo objektų raidai bei jos savitumams atskleisti, fiksuoti, pažinti; 2) lemia ir iprasmina paveldo objektų kompozicijos brandumą ir savitumus“ (Miškinis 1999: 14). Urbanistikos paveldo vertybes yra apibrèžęs ir J. Bučas, 1993-1995 m. kartu su A. Miškiniu rengęs Urbanistikos paveldo saugotiny teritoriju 1940 mety Kauno ir Klaipédos miesty administracinèse ribose projektinius pasiūlymus, - tai istorinę ir kultūrinę vertę turinčios šio paveldo teritorijos. Kultūrinè vertė nustatoma remiantis dviem kriterijais: istoriniu informatyvumu ir struktūros brandumu. Siūloma atsižvelgti $\mathfrak{i}$ tokias pagrindines urbanistinès struktūros požymių grupes:

- Urbanistinès struktūros formavimosi ypatybès (planavimo laikas ir autorius; teritorijos apstatymo laikas ir apimtis; įtraukimo į miesto žemes metai).

- Pirminès struktūros raiškumas, savitumas, ịvairovè (planinès struktūros savitumas; erdvinès struktūros kompozicinis raiškumas; apstatymo pobūdis; geokultūrinè vienovè).

- Šiandienès struktūros autentiškumas ir fizinè būklè: deformacijų pobūdis, mastas; fizinès, moralinès amortizacijos laipsnis; pirminio plano ir apstatymo apimtis; kitų kultūros vertybių (archeologijos, istorijos, architektūros, dailès) kiekis (Bučas 1995).

\section{Dabartinis teisinis urbanistikos paveldo tvarkybos pagrindas}

Atkūrus Lietuvos Respublikos nepriklausomybę, minèti vertingi urbanistikos paveldo objektai buvo įrašyti ¡ Lietuvos Respublikos Nekilnojamujų kultūros vertybiu apsaugos registrą. Šio paveldo išsaugojimas, tvarkyba ir atgaivinimas reglamentuojamas įstatymais: Lietuvos Respublikos nekilnojamojo kultūros paveldo apsaugos istatymas (2004 m. rugsèjo 28 d. Nr. IX-2452), Lietuvos Respublikos saugomu teritoriju istatymas $(2001 \mathrm{~m}$. gruodžio 4 d. Nr. IX-628) (Lietuvos... 2001, 2004). Pagrindiniai priežiūros, tvarkymo ir naudojimo dokumentai yra konkrečių urbanistinių objektų apsaugos Reglamentai. Šiame straipsnyje autore nesigilina į visas teisinių dokumentų vingrybes. Galima tik konstatuoti faktą, kad teisiné Lietuvos sistema, skirta kultūros paveldui (ne tik urbanistikos), yra gana paini, nes remiasi skirtingais istatymais ir reglamentais, o kartais pateikia pernelyg apibendrintas formuluotes, leidžiančias daryti įvairias interpretacijas. Tokią nuomonę išsake ir tarptautinès ICOMOS Ekspertų grupès nariai, kurie buvo pakviesti ịvertinti Vilniaus senamiesčio detaliojo plano projekta, parengtą $2004 \mathrm{~m}$. remiantis Vilniaus senamiesčio apsaugos reglamentu (patvirtintu $2003 \mathrm{~m}$. gruodžio $23 \mathrm{~d}$. LR kultūros ministrès įsakymu Nr. IV490) (Ehrstrom, Roald 2004; Bondin 2004).

Autore nori tik atkreipti demesí, kad atidžiau pastudijavus tiek ịstatymus, tiek ịstatymo igyvendinamuosius teisès aktus, ryškejja, kad urbanistikos paveldo objektams vietos šiuose dokumentuose nèra. Net tarp pagrindinių LR nekilnojamojo kultūros paveldo apsaugos įstatymo sąvokų tokia sąvoka neapibrežzta (2 str.). Pagal ši įstatymą saugomas arba objektas (statinys ar kitas nekilnojamasis daiktas), arba vietove (teritorija $<\ldots$. , kurioje yra kultūros paveldo objektų). Sąvoka urbanistinis atrandama tik skirstant nekilnojamąjị kultūros paveldą pagal reikšmingumą, lemiantị vertingųjų savybių pobūdị ( 3 str.). Esant tokiai situacijai, sunkumų kyla bandant suteikti urbanistikos objektams teisinị pobūdi ịrašant juos arba aprašant jau esančius Kultūros vertybiu registre. Nekilnojamoji kultūros vertybė Registre gali būti registruojama kaip pavienis kultūros paveldo objektas (pavienis objektas gali būti vieta, statinys ar kitas nekilnojamas daiktas), kompleksinis objektas arba kultūros paveldo vietové. Taigi, urbanistikos objektas gali būti ịvardintas arba kaip vieta (pavienis objektas), arba vietove (bet vietovèje turi būti arba registruotų pavienių objektų, arba kompleksų). Be to, vietovei rekomenduojama steigti rezervata, draustinị ir t. t, o čia jau galima taikyti kitą istatymą - LR saugomu teritoriju istatymą.

Nors šių metų birželio mèn. išleistas kultūros ministro Nekilnojamuju kultūros vertybiu vertinimo ir atrankos kriteriju aprašas yra papildytas ir vietovès vertingosios savybès tikrai nusako urbanistikos objekto ypatumus (įrašytos net devynios naujos sąvokos, skirtos urbanistiniam objektui apibūdinti, ir pateiktas rekomenduojamų grafinių priedų vietovei sąrašas; Nekilnojamųjų... 2011), tačiau pagrindiniai LR įstatymai, skirti kultūros paveldui (taip pat ir urbanistikos), yra orientuoti ị statinius ir gamtos objektus.

\section{Visuotinis nesusikalbëjimas urbanistikos paveldo klausimais}

Brandūs XX a. urbanistikos moksliniai tyrimai sukūrè pagrindą šių vertybių apsaugai, tačiau realybė Lietuvoje tokia - vis dar yra didelis nesusikalbejjimas urbanistikos paveldo klausimais tarp mokslo ir teisès atstovų, valdininkijos ir piliečių. Tą lemia, matyt, ne vienas veiksnys. Straipsnyje (gal kiek hipotetiškai) išskiriami keletas jų.

- Urbanistika Lietuvoje yra sąlygiškai naujas reiškinys. Lietuvos miestai kūrèsi tuo metu, kai pasaulyje jau kelis tūkstantmečius gyvavo miestų kultūros (Šešelgis 1996: 3). Lietuvoje nèra gilių urban šaknų 
tautoje. Sąvoka urban, kilusi iš lotyniško žodžio urbanus (urbs) ir reiškianti miestą, pirmą kartą buvo pavartota XVII a. pradžioje (apie 1610-1620 m.). Žodžio kilmè sietina su arimu, nes romènai turèjo tokią tradiciją (ritualą) išarti vagą aplink naują miestą, taip apibrèždami jo ribas (Cowan 2005: 415). Lietuviškų miestų kilmè yra kitokia (pvz., net Vilniaus gynybinè siena buvo juosiama tada, kai miestas egzistavo jau kelis šimtmečius). Nors sąvoka miestas turètų reikšti priešingas kaimui, mūsuose to nèra. Teisinejje kalboje, kalbant apie miestą, dominuoja "gamtinès" sąvokos, taip supriešinant gamtinius (kaip teigiamus) su miesto elementais (kaip neigiamais). Šią mintị iliustruoja Lietuvos miestų ir miestelių bendrieji planai (BP), parengti praejusiame dešimtmetyje. Juose didelis demesys skiriamas gamtiniam miesto karkasui. Nors nuo miestų kūrimosi pradžios jie buvo statomi strategiškai patogiose gamtinèse vietovėse, parengtuose miestų BP gamtinio karkaso brèžiniuose užstatymas prie upių, ežerų ịvardijamas kaip „pažeidimas“ (pažeistos gamtinio karkaso vietos). Tai sukelia vidinị prieštaravimą - ar galima saugoti tai, kas kažką pažeidžia?

- Ne vienas tarptautinis dokumentas akcentuoja, kad bet kokių paveldo vertybių apsauga bus sèkminga tik tuomet, kai jos svarbą suvoks visos kartos. Istorinių miestų ir kvartalų apsauga pirmiausia turi rūpèti jų gyventojams (Istorinių... 1987). Nepalankios istorinès aplinkybès Lietuvoje nelei- do susiformuoti stabiliam istoriškumo ir kultūros tęstinumo jausmui tautoje, todèl kultūros paveldo vertè dažną kartą suvokiama tik kaip papildoma objekto rinkos vertè. Ne retai paveldiniai objektai savininkų naudojami tik vienadienèms reikmèms tenkinti (Čepaitiené 2002). Su tokia liūdna realybe tenka susidurti dalyvaujant Kultūros paveldo departamento prie Kultūros ministerijos antrosios nekilnojamojo kultūros paveldo vertinimo tarybos posėdžiuose. Vienas iš daugelio pavyzdžių, iliustruojančių paveldo objektų savininkų požiūrị ị disponuojamą turtą, galètų būti toks: $2010 \mathrm{~m}$. Panevèžio miesto spaudoje pasirodęs skelbimas apie parduodamą žemės sklypą, kuriame yra XIX a. malūnas (pastaba: malūnas neịrašytas ị Registrą, galima griauti) žr. (4 pav.).

- Straipsnio autorès nuomone, nesusikalbëjimas tarp urbanistikos paveldo tyrëjų (mokslininkų) ir tvarkybos teisès sergètojų (valdininkų) kyla dèl bendros urbanistikos paveldo ateities vizijos, tvarkybos strategijos ir koncepcijos nebuvimo. Tokios koncepcijos nebuvimą iliustruoja ir Vilniaus senamiesčio detaliojo plano pakartotinas rengimas, kuris tęsiasi jau šeštus metus.

Mąstant apie urbanistikos paveldo ateities perspektyvas, darosi aišku, kad vieni dalykai laikui bègant išsispręs patys (turi praeiti nemažai laiko, kol mes tapsime miestietiška visuomene), kiti, tokie kaip verčiu nesuvokimas ir bendros vizijos nebuvimas, jei bus apleisti, atneš tik neigiamas pasekmes.
A

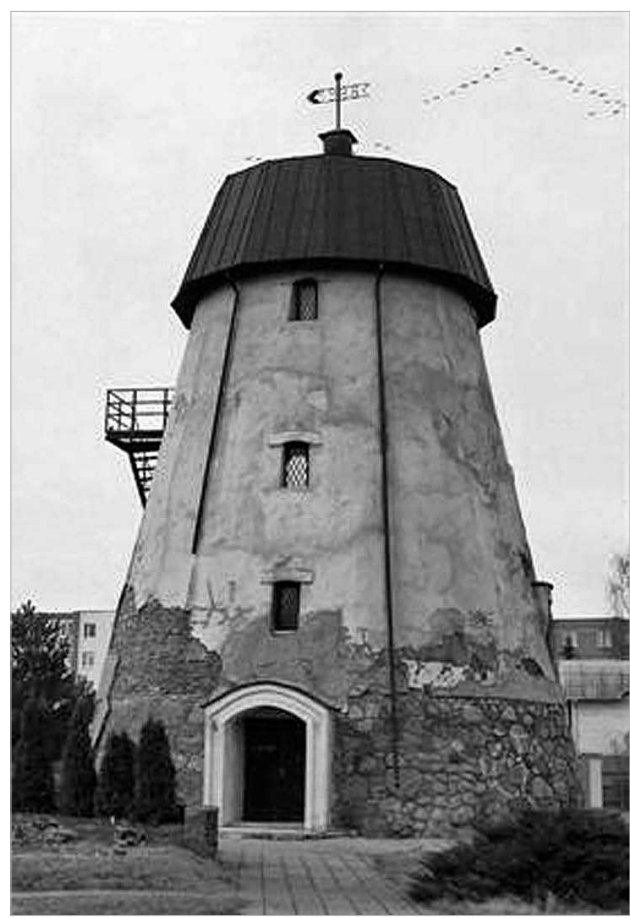

B

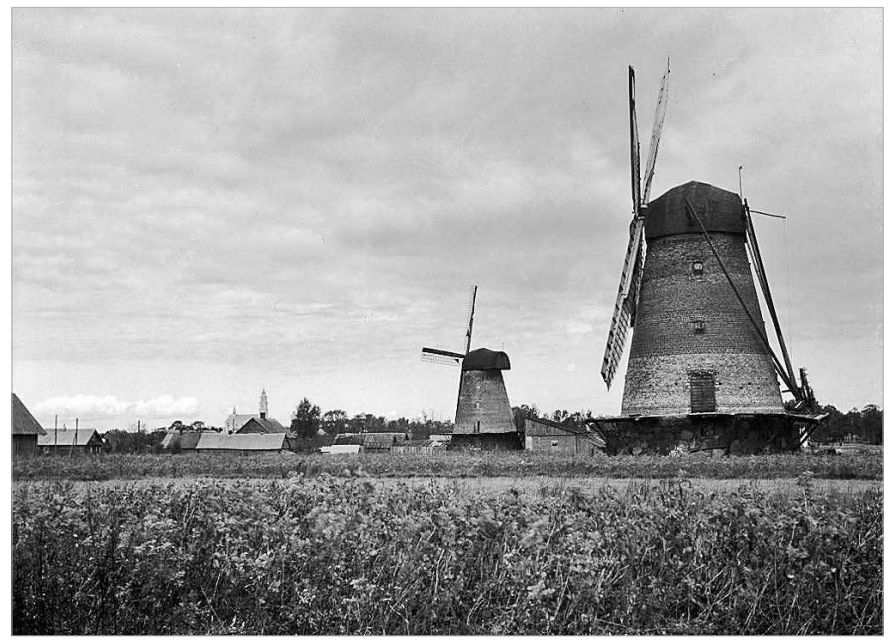

4 pav. XIX a. malūnai Panevėžyje ( $A$ - 2010 m. buvo parduodamas ir gali būti nugriautas, B - $1930 \mathrm{~m}$. nuotrauka)

Fig. 4. Mills of 19th century in Panevezys (A - 2010, for sale, "can be demolished"; B - 1930) 


\section{Apibendrinimas}

1. Propaguojamas saugoti kultūros paveldo objektas pasaulyje kito. Pati paveldo objekto sąvoka plètèsi apimdama vis naujus aspektus. Nuo pavienių objektų, paminklų apsaugos buvo einama pastatų grupių, kompleksų, miestų, vietovių saugojimo link. XXXXI a. sandūroje atsiranda labai plati kultūros paveldo objekto sąvokos interpretacija: ji apima visus imanomus ženklus, liudijančius žmonių veiklą bei pasiekimus bègant amžiams. Pasaulio materialiojo nekilnojamojo kultūros paveldo apsaugos raidoje urbanistikos paveldo objektai pradèti saugoti vèliausiai - tik XX a. antrojoje pusejje.

2. Lietuvoje esame paveldejję išsamią mokslinę tiriamąją urbanistikos paveldo vertybių nustatymo metodiką. Lietuvos urbanistikos paveldo vertingu objektų pirminis sąrašas buvo sudarytas septintajame-aštuntajame XX a. dešimtmečiuose (vèliau jis buvo tikslinamas). Urbanistinio paveldo tyrèjai (A. Miškinis, A. Pilypaitis) yra aiškiai apibrěžę šio paveldo vertybes - tai istorinę ir kultūrinę vertę turinčios miestų struktūros, plano, užstatymo ir tūrinès erdvinès kompozicijos visumos dalys, elementai ir formos, kurios yra reikšmingos viso Lietuvos urbanistikos paveldo ar atskirų jo objektų raidai bei jos savitumams atskleisti, fiksuoti, pažinti ir išryškina urbanistinio paveldo objektų kompozicijos brandumą ir savitumus. Saugomų urbanistikos paveldo objektų sąrašas nèra baigtinis - objektai yra iš naujo apsvarstomi, naujos teritorijos skelbiamos vertingomis. Urbanistikos paveldo inventorizavimas yra būtinas, tačiau saugojimo diapazonas negali plèstis be ribų, nes pats saugojimas taps nepakeliama našta tiek gyventojams, tiek valstybei.

3. Šiandieninè Lietuvos teisiné sistema, skirta nekilnojamajam kultūros paveldui (taip pat ir urbanistikos), yra paini, remiasi skirtingais įstatymais ir kitais dokumentais. Pagrindiniai LR įstatymai nèra orientuoti urbanistikos paveldui išsaugoti.

4. Norint neprarasti Lietuvos urbanistikos paveldo vertybių, tarp mokslo ir teisės atstovų, valdininkijos ir piliečių šiuo klausimu reikia mažinti nesusikalbejjimą, kylantị dèl visuomenès istorinès savivokos kokybès trūkumo ir bendros urbanistikos paveldo ateities vizijos, tvarkybos strategijos ir koncepcijos nebuvimo.

\section{Literatūra}

Bondin, R. 2004. Ataskaita apie Vilniaus Senamiesčio detalųj planą [interaktyvus]. $2004 \mathrm{~m}$. gruodžio $22 \mathrm{~d}$. [žiūrèta $2011 \mathrm{~m}$. spalio 14 d.]. Prieiga per internetą: $<\mathrm{http}: / / \mathrm{www}$. vsaa.lt/RayBondin_ataskaita.doc $>$.

Bučas, J. 1995. Urbanistikos paveldo saugotinos teritorijos, Urbanistika ir architektūra [Town Planning and Architecture] 1-2(19-20): 156-172.
Cowan, R. 2005. The dictionary of urbanizm. Streetwise Press.

Čepaitienè, R. 2002. Požiūriai ị kultūros paveldą dabarties Lietuvoje, Kultūros paminklai 9: 10-19.

Čepaitienė, R. 2005. Laikas ir akmenys. Kultūros paveldo sampratos moderniojoje Lietuvoje. Vilnius: LII leidykla. 468 p.

Čepaitienè, R. 2010. Paveldosauga globaliajame pasaulyje. Vilnius: LII leidykla. $140 \mathrm{p}$.

Dijokienė, D. 2002. Istoriniai priemiesčiai: genezé, raida, verte, tvarkymas (Lietuvos miestu pavyzdžiu): daktaro disertacijos santrauka. Vilnius: Technika. $40 \mathrm{p}$.

Dijokiené, D. 2009. Urbanistinis istoriniu priemiesčiu paveldas [Urban heritage of historical suburbs]. Vilnius: Technika. 216 p. ISBN 978-995-528-473-4.

Ehrstrom, M.; Roald, H. J. 2004. Ataskaita apie paveldo vertybiu apsauga Vilniuje (Lietuva), ypatinga demesį skiriant dviem planavimo dokumentams - Vilniaus senamiesčio apsaugos reglamentui ir Vilniaus senamiesčio detaliojo plano projektui [interaktyvus], $2004 \mathrm{~m}$. gruodžio $22 \mathrm{~d}$. [žiūrèta $2011 \mathrm{~m}$. spalio 14 d.]. Prieiga per internetą: <http://www.vsaa.lt/ Margaret_ataskaita.doc $>$.

Jurkštas, V. 1975. Kauno senamiesčio tūrinè-erdvinė kompozicija, Architektūros paminklai [Town Planning and Architecture] 3: 98-120.

Miškinis, A. 1999. Lietuvos urbanistikos paveldas ir jo vertybès. Užnemunès miestai ir miesteliai. I t. Vilnius: Savastis.

Miškinis, A. 1999, 2002, 2004, 2005, 2007, 2009. Lietuvos urbanistikos paveldas ir jo vertybès (šeši tomai). Vilnius: Savastis.

Miškinis, A. 2005. Lietuvos urbanistikos paveldas: vertybiu iteisinimas, apsauga, tvarkymas (1967-1993). Dokumentu rinkinys.Vilnius: Savastis. 212 p.

Šešelgis, K. 1996. Lietuvos urbanistikos istorijos bruožai (Nuo seniausiu laiku iki 1918 m.). Vilnius: Mokslo ir enciklopedijų leidykla. $160 \mathrm{p}$.

Zaleckis, K.; Matijošaitienė, I. 2011. Urbanistinis genotipas: kai kurie aspektai ir jų kaitos tyrimai, Urbanistika ir architektūra [Town Planing and Architecture] 35(2): 73-81. doi:10.3846/tpa.2011.09

Шешельгис, К. 1963. О методике архитектурно-художественного исследования города (на примере г. Вильнюса), LTSR aukštųjų mokyklų mokslo darbai, Statyba ir architektūra, Nr. 3 .

\section{Tarptautiniai teisės aktai (UNESCO, ICOMOS, Europos Tarybos)}

Declaration of Tlaxcala [interaktyvus]. The Revitalization of Small Settlements. 1982. Adopted in Trinidad, Tlaxcala, 25-28 October [žiūrèta $2011 \mathrm{~m}$. spalio 14 d.]. Prieiga per internetą: <www.icomos.org/docs/tlaxcala.html>.

First Conference of European Ministers Responsible of the Cultural Heritage of Monuments and Sites [interaktyvus]. 1969. Adopted in Brussels, 25-27 November [žiūrèta 2011 m. spalio 14 d.]. Prieiga per internetą: <http://www.international.icomos.org/centre_documentation/coe_eng.htm>.

ICOMOS Charter - Principles for the Analysis, Conservation and Structural Restoration of Architectural heritage [interaktyvus]. 2003 [žiūrèta $2008 \mathrm{~m}$. rugpjūčio 19 d.]. Prieiga per internetą: <http://www.international.icomos.org/ charters/structures_e.pdf $>$.

Istoriniu miestu apsaugos chartija (Vašingtono chartija, 1987). Kultūros paveldo apsauga (reglamentuojančiu dokumentų rinkinys). 1997. Vilnius: Savastis, 246-249. 
Kultūros vertybiu apsaugos ginkluoto konflikto atveju konvencija. 1954. Kultūros paveldo apsauga (reglamentuojančių dokumentų rinkinys). 1997. Vilnius: Savastis, 128-170.

Quebec Declaration on the Preservation of the Spirit of Place through the Safeguarding of Tangible and Intangible Heritage [interaktyvus]. 2008. Adopted at Quebec City, Canada [žiūrèta $2011 \mathrm{~m}$. spalio 14 d.]. Prieiga per internetą: $<\mathrm{http}: / / \mathrm{www}$.international.icomos.org/ quebec2008/quebec_declaration/pdf/GA16_Quebec_ Declaration_Final_EN.pdf $>$.

Recommendation No R (86) 11 of the Committee of Ministers to member States on urban open space [interaktyvus]. 1986. Adopted by the Committee of Ministers on 12 September [žiūrèta $2011 \mathrm{~m}$. spalio 14 d.]. Prieiga per internetą: <https://wcd.coe.int/wcd/com.instranet. InstraServlet?command $=$ com.instranet.CmdBlobGet\&Inst ranetImage $=551137 \&$ SecMode $=1 \&$ DocId $=74010 \&$ Usage $=2>$.

Resolution (68) 12 on the Active Maintenance of Monuments, Group and Areas of Buildings of Historical or Artistic Interest within the Context of Regional Planning [interaktyvus]. 1968. Adopted by the Ministers' Deputies on 3rd May [žiūrèta $2011 \mathrm{~m}$. spalio 14 d.]. Prieiga per internetą: $<$ https://www6.euskadi.net/r46-4874/es/contenidos/ informacion/manifiestos_patrimonio/es_8658/adjuntos/ DOC30.pdf $>$.

Resolutions of the International Symposium on the Conservation of Smaller Historic Towns, at the 4th ICOMOS General Assembly [interaktyvus]. 1975. Adopted in Rothenburg ob der Tauber, 29-30 May [žiūrèta $2002 \mathrm{~m}$. sausio $30 \mathrm{~d}$.]. Prieiga per internetą: <www.icomos.org/ docs/small_towns.html>.

Suzhou Declaration on International Co-operation for the Safeguarding and Development of Historic Cities [interaktyvus]. 1998. Adopted in Suzhou, 9 April [žiūrèta $2002 \mathrm{~m}$. sausio 30 d.]. Prieiga per internetą: <http://www.iicc.org. $\mathrm{cn} /$ Info.aspx? ModelId $=1 \& \mathrm{Id}=454>$.

Tarptautine paminklu ir kompleksu konservavimo ir restauravimo chartija (Venecijos chartija, 1964). Kultūros paveldo apsauga (reglamentuojančių dokumentų rinkinys). 1997. Vilnius: Savastis, 236-239.

The Athens Charter of the Restoration of Historic Monuments [interaktyvus]. 1931. Adopted at the First International Congress of Architects and Technicians of Historic Monuments, Athens [žiūrèta $2002 \mathrm{~m}$. sausio 30 d.]. Prieiga per internetą: $<$ http://www.icomos.org/docs/athens_charter.html>.

The Norms of Quito [interaktyvus] (Final Report of the Meeting on the Preservation and Utilization of Monuments and Sites of Artistic and historical Value held in Quito, Ecuador, from November 29 to December 2, 1967) [žiūrèta $2011 \mathrm{~m}$. rugsèjo 8 d.]. Prieiga per internetą: $<$ http://www.icomos.org/docs/quito67.html>.

Vienna Memorandum on World Heritage and Contemporary Architecture - Managing the Historic Urban Landscape [interaktyvus]. 2005 [žiūrèta $2011 \mathrm{~m}$. rugsèjo 8 d.]. Prieiga per internetą: $<$ http://whc.unesco.org/uploads/activities/ documents/activity-48-3.doc $>$.

$X i$ 'an Declaration on the Conservation of the Setting of Heritage Structures, Sites and Areas [interaktyvus]. 2005 [žiūrèta 2008 m. rugpjūčio 19 d.]. Prieiga per internetą: $<$ http://www.international.icomos.org/charters/xiandeclaration.pdf $>$.

\section{Lietuvos teisès aktai}

Lietuvos Respublikos nekilnojamojo kultūros paveldo apsaugos istatymas [interaktyvus] 2004. Nr. IX-2452 [žiūrèta $2011 \mathrm{~m}$. spalio 14 d.]. Prieiga per internetą: <http://www3. lrs.lt/pls/inter3/dokpaieska.showdoc_l?p_id=243075>.

Lietuvos Respublikos saugomu teritoriju įstatymas [interaktyvus]. 2001. Nr. IX-628 [žiūrèta 2011 m. spalio 14 d.]. Prieiga per internetą: $<$ http://www3.lrs.lt/pls/inter3/ dokpaieska.showdoc_l?p_id=156931>.

Nekilnojamujų kultūros vertybiu vertinimo ir atrankos kriteriju aprašas. 2011. Patvirtintas LR kultūros ministro 2011 m. birželio 15 d. ịsakymu Nr. İV-447.

\section{Archyviniai šaltiniai}

Jurevičienè, J.; Ivaškevičius, E.; Gučas, A.; Kaikaras, R. 1990. Vilniaus senamiesčio ir kitu urbanistiniu paminkliniu teritoriju projektas. Vilniaus apskrities archyvas, F2-101-170.

Pilypaitis, A.; Miknevičienè, G.; Gučas, A.; Jurevičienè, J. 1993. Vilniaus miesto centrines dalies (1940 m. miesto ribose) paminklinių teritoriju statuso pasiūlymai. Vilniaus apskrities archyvas, F2-101-208.

\section{ORIGINS AND PRESENT SITUATION OF URBAN HERITAGE MANAGEMENT IN LITHUANIA}

\section{Dijokienè}

Abstract. The concept of urban heritage value in the mind of the humankind is relatively new. Protection of urban heritage objects started at the latest in the development of the global tangible objects of immovable cultural heritage. Protection of these objects has been developing as an opposition to dominating urbanisation processes. The article briefly reviews evolution of the notion and object of cultural heritage in documents of international organisations in the $20^{\text {th }}$ and $21^{\text {st }}$ centuries and looks into when this notion expands to encompass urban compositions. It analyses the solid scientific framework of the Lithuanian urban heritage research upon which the interpretation and legalisation was founded. The article discuses the present-day legal framework of urban heritage management, pointing out its drawbacks. It seeks to identify why scientists and lawyers, as well as members of government and the public fail to find a common language on issues of urban heritage management.

Keywords: town, old town, historical centre, urban heritage, urban heritage value, development of urban structures that formed in the course of history, immovable cultural heritage, regulation

\section{DALIA DIJOKIENE}

Doctor of the Humanities (architecture), Assoc. Prof., Dept of Urban Design, Vilnius Gediminas Technical University, Pylimo g. 26/Traku g. 1, 01132 Vilnius, Lithuania.

E-mail:dijokai@takas.lt.

Research interests: urban nuances of town spatial expansion beyond the old town's borders. Conferences: reports at 5 international and 7 national conferences. Publications: author of monograph and research papers. Teaching: lectures of architectural and urban design. Projects: author or co-author of more than 30 projects of architectural design and planning. 